\title{
LAPAROSCOPIC RESECTION OF GASTROINTESTINAL STROMAL TUMORS (GIST)
}

\author{
Ressecção laparoscópica de tumores estromais gastrintestinais (GIST)
}

Marcelo de Paula LOUREIRO 1,2, Rômulo Augusto Andrade de ALMEIDA², Christiano Marlo Paggi CLAUS 1,2, Eduardo Aimoré BONIN ${ }^{1,2}$, Antônio Moris CURY-FILHO', Daniellson DIMBARRE ${ }^{1}$, Marco Aurélio Raeder da COSTA ${ }^{1}$, Marcílio Lisboa VITAL ${ }^{1,2}$

From the ${ }^{1}$ Instituto Jacques Perissat and ¿Universidade Positivo ('Jacques Perissat Institute and ${ }^{2}$ Positivo University), Curitiba, PR, Brazil
ABSTRACT - Background: Gastrointestinal mesenchymal or stromal tumors (GIST) are lesions originated on digestive tract walls, which are treated by surgical resection. Several laparoscopic techniques, from gastrectomies to segmental resections, have been used successfully. Aim: Describe a single center experience on laparoscopic GIST resection. Method: Charts of 15 operated patients were retrospectively reviewed. Thirteen had gastric lesions, of which ten were sub epithelial, ranging from $2-8 \mathrm{~cm}$; and three were pure exofitic growing lesions. The remaining two patients had small bowel lesions. Surgical laparoscopic treatment consisted of two distal gastrectomies, 11 wedge gastric resections and two segmental enterectomies. Mechanical suture was used in the majority of patients except on six, which underwent resection and closure using manual absorbable sutures. There were no conversions to open technique. Results: Mean operative time was $1 \mathrm{~h} 29 \mathrm{~min} \pm 92$ (40-420 min). Average lenght of hospital stay was three days (2-6 days). There were no leaks, postoperative bleeding or need for reintervention. Mean postoperative follow-up was 38 \pm 17 months (6-60 months). Three patients underwent adjuvant Imatinib treatment, one for recurrence five months postoperatively and two for tumors with moderate risk for recurrence. Conclusion: Laparoscopic GIST resection, not only for small lesions but also for tumors above $5 \mathrm{~cm}$, is safe and acceptable technique.
HEADINGS - Laparoscopy. GIST. Surgery. Gastrectomy. Enterectomy.
RESUMO - Racional : Os tumores estromais ou mesenquimais gastrointetinais (GIST) são lesões originárias da parede do tubo digestivo cujo tratamento requer remoção cirúrgica. Diversas técnicas por via laparoscópica - gastrectomias e ressecções segmentares - têm sido empregadas com sucesso. Objetivo: Apresentar a experiência de um serviço de cirurgia com ressecção laparoscópica de GIST. Métodos: Foram avaliados 15 pacientes com GIST operados revisados retrospectivamente. Treze tiveram lesões gástricas, das quais 10 eram subepiteliais entre $2-8 \mathrm{~cm}$. Três eram lesões exofíticas puras. Dois apresentavam lesões no intestino delgado. O tratamento cirúrgico por laparoscopia consistiu de duas gastrectomias distais; 11 ressecções gástricas em cunha e duas enterectomias segmentares. Sutura mecânica foi utilizada na maioria dos doentes, exceto em seis com suturas absorvíveis manuais. Não houve conversões

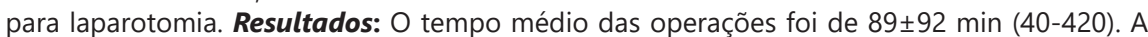
hospitalização média foi de três dias (2-6). Não houve fístula, sangramento pós-operatório ou necessidade de reintervenção por complicação cirúrgica. O seguimento médio pós-operatorio foi de 38 \pm 17 meses (6-60). Três pacientes foram encaminhados para terapia adjuvante com mesilato de imatinib, um deles por recidiva precoce aos cinco meses, e os outros dois por apresentarem risco moderado para recidiva. Conclusão: A ressecção laparoscópica de GIST, mesmo os maiores de $5 \mathrm{~cm}$, é procedimento factível e seguro.
DESCRITORES: Laparoscopia. GIST. Cirurgia. Gastrectomia. Enterectomia..

\section{INTRODUCTION}

G astrointestinal stromal or mesenquimal tumors (GIST) are lesions originated from digestive tube walls, which tend to occur in individuals older than 60 years. Its anual incidence is 10 cases per million inhabitants 12,17 . This entity derives from the Cajal's cell membrane receptor C-kit mutation. Cajal's cells are also known as intestinal pacemaker cells ${ }^{15}$. Such mutation has direct influence on proliferation and cell death. GIST definite diagnosis is only possible in the presence of CD117 (CKit) marker on immunohistochemistry, positive in over $95 \%$ of the cases $^{26}$. GIST tumors are intramural growing lesions, which makes its biopsy very challenging. They usually present on a variable biological behavior, being benign in the majority of cases. Around $30 \%$ present as clinically malignant lesions ${ }^{8}$. Treatment is surgical complete resection. Neoadjuvant chemotherapy sometimes is indicated in the management of large lesions. Adjuvance is reserved for recurrence or unresectable metastasis ${ }^{16,24}$.

GISTs surgical resections can be performed either laparoscopically or as open conventional procedures ${ }^{1,28}$. There are no available randomized studies comparing the two approaches. Series of patients or case-control studies are, therefore, the best source to evaluate pros and cons of each technique.

The aim of this study was to report a single center experience on laparoscopic GIST resection. 
METHODS

A retrospective non-comparative review of confirmed GIST cases was performed in a single center. Patients harboring submucosal gastric lesions larger than $2 \mathrm{~cm}$ were evaluated by endoscopic ultrasound when available, and then submitted to either resection or close follow up. Suspicious lesions on patients being considered for bariatric surgery were resected before or during the bariatric procedure according to tumor location. Non-gastric lesions were included in the review only if GIST diagnosis was confirmed.

All patients with primary gastric GISTs were initially prepared for laparoscopic resection. The resection techniques were chosen according to tumor location. Therefore local resections, wedge resections and partial gastrectomies were performed. Small bowel lesions were treated by segmental intestinal resections. Wedge resections were performed either with or without mechanical stapling devices, according to surgeon's preference. Laparoscopic access to cavity followed classical techniques previously described. Special care was taken in order to avoid tumor capsule rupture during specimen handling and extraction from the cavity. Specimen retrieval was performed through a special pouch (Endocatch, Covidien).

Baseline data including gender, age, body mass index (BMI), symptoms and signs, endoscopy and image findings, previous abdominal operations, operation time, length of stay, complications, re-interventions and readmissions on six months period were collected. Patients were classified according to prognostic criteria of risk related to recurrence and tumor death (Table 1). Operated patients were submitted to laboratory and clinical follow up. Patients with metastatic disease at time of resection and patients operated without histologic confirmation of GIST were excluded from the study.

TABLE 1 - Risk stratification for primary GIST by mitosis ratio, tumor size and location.

\begin{tabular}{|c|c|c|c|c|}
\hline \multirow{2}{*}{$\begin{array}{l}\text { Mitosis } \\
\text { ratio }\end{array}$} & \multirow{2}{*}{ Tumor size } & \multicolumn{3}{|c|}{ Location risk* } \\
\hline & & Gastric & Small Bowell & Rectum \\
\hline \multirow{4}{*}{$\begin{array}{c}\leq 5 \text { per } \\
\text { HPF }\end{array}$} & $\leq 2 \mathrm{~cm}$ & Very Low & Very Low & Very Low \\
\hline & $>2 \mathrm{~cm}$ and $\leq 5 \mathrm{~cm}$ & Low & Low & Low \\
\hline & $>5 \mathrm{~cm}$ and $\leq 10 \mathrm{~cm}$ & Low & Moderate & Insufficient Data \\
\hline & $>10 \mathrm{~cm}$ & - & High & High \\
\hline \multirow{4}{*}{$\begin{array}{c}>5 \text { per } \\
\text { HPF }\end{array}$} & $\leq 2 \mathrm{~cm}$ & Low & High & High \\
\hline & $>2 \mathrm{~cm}$ and $\leq 5 \mathrm{~cm}$ & Moderate & High & High \\
\hline & $>5 \mathrm{~cm}$ and $\leq 10 \mathrm{~cm}$ & High & High & Insifficient Data \\
\hline & $>10 \mathrm{~cm}$ & High & High & High \\
\hline
\end{tabular}

$\mathrm{HPF}=$ high power field; ${ }^{*}=$ defined by metastasis or tumor related death (Adapted from Miettinen\&Lasota)

RESULTS

Between January 2009 and October 2013, 15 patients with GIST diagnosis were operated in the Division of General Surgery, Jacques Perissat Institute, Curitiba, PR, Brazil. Patients characteristics are presented on Table 2.

TABLE 2 - Patient base characteristics and tumor location.

\begin{tabular}{lc}
\hline Characteristics & GIST $(n=15)$ \\
\hline Gender: female/male, $n(\%)$ & $9(66 \%) / 6(33 \%)$ \\
\hline BMI mean \pm SD (variation), kg/m² & $26 \pm 12(20-40)$ \\
\hline Tumor location gastric/intestinal n (\%) & $12(80 \%) / 3(20 \%)$ \\
\hline BMI=body mass index &
\end{tabular}

Seven patients (46\%) were completely asymptomatic being diagnosed with GISTs on routine image exams, on preparatory workout or even during the operation for GERD disease or bariatric procedure. Among symptomatic individuals, two complained of melena, three epigastric pain, one dysphagia, one post-meal vomits and one tenesmus.

All patients, no matter location of the lesion, underwent an upper $\mathrm{Gl}$ endoscopy. During the exam were identified 10 submucosal gastric lesions ranging from 2 to $8 \mathrm{~cm}$, one of them presenting a central ulceration. Out of these ten lesions, four were on the lesser curvature, two in fundus, three in antrum and one in gastric body.

Theother fivelesionswere notvisualized on upperGl endoscopy. Three of them were purely exofitic growing and the other two were originated from small bowel. Those lesions were diagnosed by abdominal CT scan (three lesions) and as incidental findings during upper GI surgery (two lesions). Echoendoscopy and biopsy were performed on three cases, being conclusive in only one of them.

Nine patients underwent abdominal operations before GIST resections. Only one of them had a major procedure as a treatment of severe acute pancreatitis. Those interventions did not have any impact on the laparoscopic approach.

All patients underwent laparoscopic resection. Two distal gastrectomies, eleven wedge resections and two segmental small bowel resections were performed. Mechanical stapling devices were used on the majority of cases, but for six the procedures were accomplished by opening the gastric wall with ultrasonic scalpel, resecting the tumors and closing it with absorbable running sutures (Figure 1). There were no conversions. Mean operative time was 1 $\mathrm{h}$ and $29 \mathrm{~min} \pm 92$ (40-420 $\mathrm{min})$.

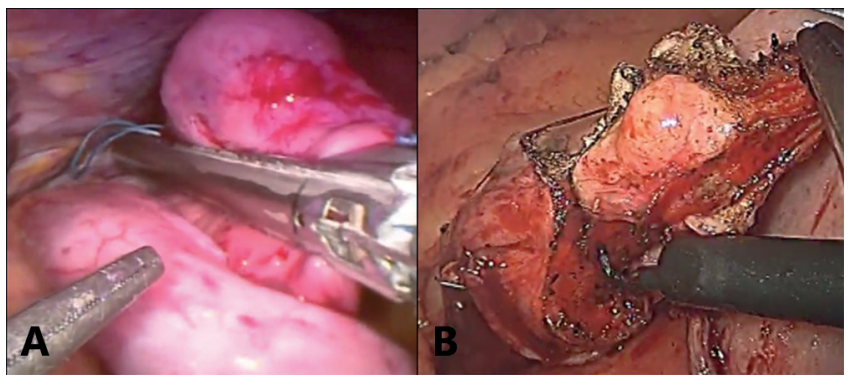

FIGURE 1 - A) Posterior gastric wall accessed through the anterior gastric wall with GIST wedge resection using mechanical laparoscopic sutures; B) anterior gastric wall GIST wedge-resected using monopolar energy followed by gastrorrhaphy

All frozen surgical margins were negatives except one of the cases as frozen sections was not available at the time of surgery and it was not performed. Paraffin histology on that last case showed positive margins and patient was brought to the operation room six weeks later for margin extension still by laparoscopy (Figure 2).

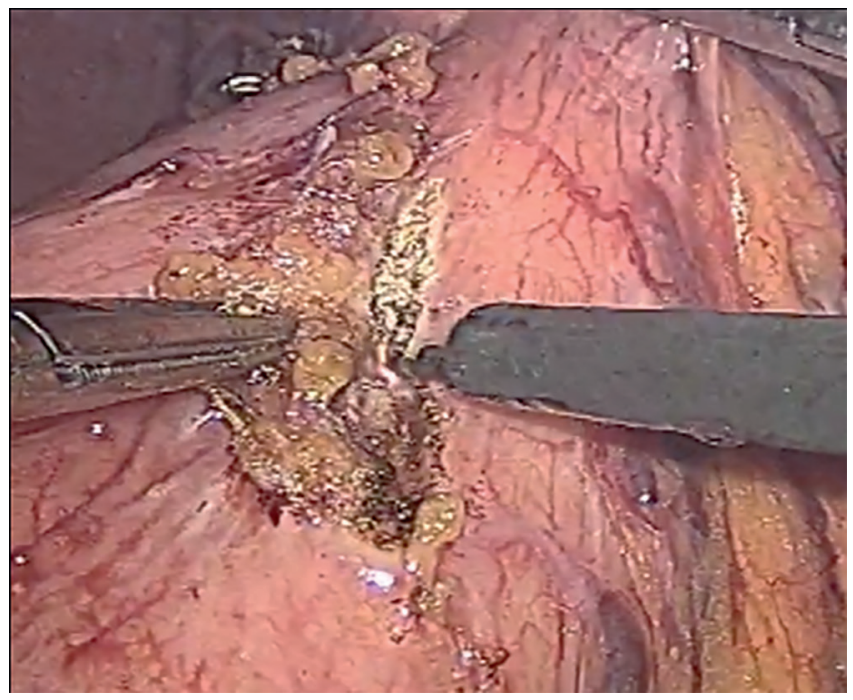

FIGURE 2 - Surgical margin resection after confirmed positive margin 
The predominat histology type was the fusiform, observed on 14 patients (93\%), followed by the epithelioid in only one patient $(7 \%)$.

Immunohistochemistry pannel analysis showed positive CD117 and CD34 on 14 patients (93\%). Ki67 marker was positive on eight patients (53\%) and desmin was seen on five (33\%).

The mean lenght of hospital stay was three days (2-6). There were no need for early surgical reinterventios, no leakages nor post-operative bleeding. One of the procedures took 7 $\mathrm{h}$ and the same patient stayed longer in hospital secondary to prolonged postoperative ileus. Excluding a single patient reoperated for positive margins, there was no postoperative complications .

Table 3 list patients according to prognosis classification.

TABLE 3 - Recurrence risk or death related according to tumor characteristics

\begin{tabular}{|c|c|c|c|c|c|}
\hline Patient & HPF mitosis $(\mathrm{n})$ & Tumor size $(\mathrm{cm})$ & Location & Risk \\
\hline 1 & 0 & $<2$ & stomach & Very Low \\
\hline 2 & 0 & $>5$ & stomach & Low \\
\hline 3 & 0 & $<2$ & stomach & Very Low \\
\hline 4 & 5 & 2 a 5 & stomach & Low \\
\hline 5 & 0 & 2 a 5 & stomach & Low \\
\hline 6 & 2 & 2 a 5 & stomach & Low \\
\hline 7 & 0 & $<2$ & stomach & Very Low \\
\hline 8 & 0 & 2 a 5 & ileum & Low \\
\hline 9 & 5 & 2 a 5 & stomach & Low \\
\hline 10 & 5 & $>5$ & stomach & Low \\
\hline 11 & 10 & 2 a 5 & stomach & Moderate \\
\hline 12 & 5 & 2 a 5 & stomach & Low \\
\hline 13 & 5 & $>5$ & stomach & Low \\
\hline 14 & $>50$ & 2 a 5 & stomach & Moderate \\
\hline 15 & 5 & 2 a 5 & jejunum & Low \\
\hline HPF high power field & & & \\
\hline
\end{tabular}

Mean follow-up was 38 month \pm 17 (6-60 months). At the present time three patients are undergoing adjuvant imatinib therapy. Two of them for moderate recurrence risk and one for early recurrence of the disease.

\section{DISCUSSION}

Gastrointestinal stromal tumors are complex from its diagnosis to treatment. The patient's baseline characteristics, and surgical specimen immunohistochemistry patterns (CD117 and CD34) are comparable to Brazilian and world literature ${ }^{14,23}$ Around $5 \%$ of GISTs are expected to be CD117 negative. Was observed that incidence in this series $(n=1,7 \%)$.

Patients are usually asymptomatic or present vague symptoms ${ }^{4,23}$.Therefore GISTs are often diagnosed incidentally ${ }^{23}$.

According to guidelines of the European Society for Medical Oncology (ESMO) tumors larger than $2 \mathrm{~cm}$ should be removed. Lesions under $2 \mathrm{~cm}$ should be followed periodically by upper $\mathrm{Gl}$ endoscopy and biopsy; resection must be done if tumor growth is observed ${ }^{3}$. In this series, few patients were evaluated by echoendoscopy due to its difficult access by the time the patients were attended.

Histopathologic evaluation of GISTs usually shows predominant fusiform type (70\%). The incidence of epithelioid and the mixed types was $20 \%$ and $10 \%$ respectivally ${ }^{13,23}$. Cytological analysis of the surgical specimens demonstrated fusiform or spindle cell predominance (93\%).

GIST treatment could be achieved through a multimodalities approach, but surgical resection remains the primary focus ${ }^{27}$. Target therapy or even radiotherapy can be used in some exceptional cases and multiple procedures maybe needed for recurrent lesions.

Laparoscopic primary GIST resection should be considered by surgeons with advanced laparoscopic skills ${ }^{7,21}$. Laparoscopic
GIST resection has the advantages over the open conventional approaches as being more precise procedure and results, with better postoperative and immunological outcome, but these findings still need to be confirmed.

A great variability among laparoscopic techniques used in the present study correlates with the disease heterogeneous nature. Procedures ranged from mechanical stapling wedge resections to distal gastrectomies. Oncology principles can be efficiently respected in the laparoscopic approach and larger lesions $(>5 \mathrm{~cm}$ ) as well. Three patients in the study had large lesions. Free surgical margins should be the treatment goal confirmed by the frozen sections. Positive margins should be removed at the primary resection or during reoperation if diagnosis was performed on paraffin sections.

Tumor capsule should be preserved in order to avoid trocars seeding, and direct contact with the lesion should also be avoided. Reoperations for margin resection can be done laparoscopically as was done in one of these cases.

Han (2012) considers tumor capsule violation as a worsening prognostic factor. When it occurs, patients should be treated with routine adjuvant therapy ${ }^{9,10}$.

Comparable results were published by other authors $5,19,20,25$. Novitsky (2006) reported 50 laparoscopic resections. Average tumor size was $4 \mathrm{~cm}$ and $8 \%$ recurrence rate (mainly hepatic metastasis) was observed over a 36 months follow-up ${ }^{25}$. Similar to these findings, his patients did not develop local recurrence or trocar site metastasis. The author considers the laparoscopic approach superior for GIST surgical treatment, especially for gastric lesions. This opinion is shared by our group.

Among prognostic criteria, mitosis index is the most related to recurrence ${ }^{2,22}$. In these authors experience, patient with higher number of mitosis per 50 HPF analysis suffered early disease recurrence.

Continued adjuvant chemotherapy use on high risk GIST patients without documented local recurrence or metastasis is still being a matter of discussion ${ }^{6,8,11,18}$. Some studies showed efficacy of this practice with disease free interval increase ${ }^{6,11}$. This choice has to be considered by the medical oncologist and the high risk GIST patient.

\section{CONCLUSION}

Laparoscopic GISTs resection for primary gastric and intestinal lesions seems to be feasible and safe. Comparative studies from larger series of patients are needed to evaluate more advantages of laparoscopic approaches.

\section{REFERENCES}

1. BarrosF, Nahoum, GuilhermePA, Bruno J. Treatment of gastrointestinal stromal tumor (GIST) during bariatric surgery. Rev Col Bras Cir 2015; 42(1): 67 - 68.

2. Blackstein ME, Blay JY, Corless $C$, Driman DK, Riddell R, Soulières $D$, et al. Gastrointestinal stromal tumours: consensus statement on diagnosis and treatment. Can J Gastroenterol 2006; 20(3):157 - 163

3. Casali PG, Jost L, Reichardt P, Schlemmer M, Blay JY. Gastrointestinal stromal tumours: ESMO clinical recommendations for diagnosis, treatment and follow-up. Ann Oncol 2009; 20: 64 - 67.

4. Cruz Júnior RJ, Glyniadakis N, Cavalcante RN, Cepeda LA, Vincenzi R. Hemorragia digestiva provocada portumorestromal gastrointestinal avançado de duodeno. Arq Bras Cir Dig 2007; 20(4):290 - 292.

5. Dematteo RP, Gold JS, Saran L, Gönen M, Liau KH, Maki RG, et al. Tumor mitotic rate, size, and location independenly predict recurrence after resection of primary gastrointestinal stromal tumor (GIST). Cancer 2008; 112 (3): 608 - 615.

6. Essat M, Cooper K. Imatinib as adjuvant therapy for gastrointestinal stromal tumors: a systematic review. Int J Cancer 2011; 128 (9): $2202-2214$.

7. Everett M. Gutman H. Surgical management of gastrointestinal stromal tumors: analysis of outcome with respect to surgical margins and technique. J Surg Oncol 2008: 98(8): 588 - 93. 
8. Grotz TE, Donohue JH. Surveillance strategies for Gastrointestinal Stromal Tumors. J Sur Oncol 2011; 104(8): 921 - 927.

9. Han D, Deneve J, Gonzalez RJ. Recurrence risk after resection of Gastrointestinal Stromal Tumors: size is not all that matters... the consequences of tumor rupture. Am Surg 2012; 78(1): 74 - 79.

10. Joensuu, H. Riskstratification of patients diagnosed with gastrointestinal stromal tumor. Hum Pathol 2008; 39(10): 1411 - 1419.

11. Joensuu $H$, Eriksson M, Hall KS. One vs three years of adjuvant Imatinib for operable gastrointestinal stromal tumor. JAMA 2012; 307(12): $1265-1272$.

12. KinghamTP,DeMatteoRP.MultidisciplinarytreatmentofGastrointestinal Stromal Tumors. Surg Clin N Am 2009; 89(1): 217 - 233.

13. Linhares $E$, Gonçalves R, Valadão M, Vilhena B, Herchenhorn D, Romano S, et al. Tumor estromal gastrointestinal:análise de 146 casos do centro de referência do Instituto Nacional do Câncer INCA. Re. Col Bras Cir 2011; 38(6): 398 - 406.

14. Lopes LF, Ojopi EB, Bacchi CE. Gastrointestinal stromal tumor in Brazil: clinicopathology, immunohistochemistry, and molecular genetics of 513 cases. Pathol Int 2008; 58(6): 344 - 352.

15. Lorincz A. Redelman D. Horvath VJ. et al. Progenitors of interstitial cells of Cajal in the postnatal murine stomach. Gastroenterology 2008; 134(4): 1083 - 93.

16. Lourenço LG, Caponero R. Tratamento adjuvante nos GISTs. Arq Bras Cir Dig 2011; 24(3): 239 - 241.

17. Mucciarini C, Rossi G, Bertolini F, Valli R, Cirilli C, Rashid I, et al. Incidence and clinicopathologic features of gastrointestinal stromal tumors: a population-based study. BMC Cancer 2007; 20(7): 230.

18. National ComprehensiveCancer Network. Clinical Practice Guidelines in Oncology for Soft Tissue Sarcoma. Version 2. Fort Washington, Pa: National Comprehensive Cancer Network; 2009.

19. Nguyen SQ, Divino CM, Wang JL, DikmanSH. Laparoscopicmanagement of gastrointestinal tumors. Surg Endosc 2006; 20(5):713 - 6 .

20. Nishimura J, Nakajima K, Omori T, Takahashi T, Nishitani A, Ito T, et al. Surgical strategy for gastric gastrointestinal tumors: laparoscopic vs. open resection. Surg Endosc 2007; 21(6): 875 - 8 .

21. Novitsky YW, Kercher KW, Sing RF, Heniford BT. Longterm outcomes of laparoscopic resection of gastric gastrointestinal stromal tumors. Ann Surg 2006; 243(6): 738 - 45; discussion 45-7.

22. Oliveira RP, Portari Filho $\mathrm{PE}$, Iglesias $A C$, Oliveira CA, Pannain VL.Comparativestudy of the different degrees of risk of gastrointestinal stromal tumor. Rev Col Bras Cir 2015; 42(1): 32 - 36.

23. Patil, DT, Rubin, BP. Gastrointestinal Stromal Tumor Advances in Diagnosis and Management. Arch Pathol Lab Med 2011; 135(10): $1298-1310$.

24. Pisters PWT, Patel SR. Gastrointestinal Stromal Tumors: current management. J Surg Oncol 2010; 102(5): 530 - 538.

25. Pucci MJ, Berger AC, Lim PW, Chojnacki KA, Rosato El, Palazzo F. Laparoscopic approaches to gastric gastrointestinal stromal tumors: an institutional review of 57 cases. Surg Endosc 2012; 26(12): 3509 - 3514.

26. Rubin BP, Blanke CD, Demetri GD, DeMatteo RP, Fletcher $C D$, Goldblum JR, et al. Protocol for the examination of specimens from patients with gastrointestinal stromal tumor. Arch Pathol Lab Med 2010; 134(2): 165 - 170.

27. Valadão $\mathrm{M}$, Linhares $\mathrm{E}$. O papel atual do cirurgião no tratamento do GIST. Rev Col Bras Cir 2009; 36(3): 261 - 265.

28.Zia MK, Morris-Stiff G, Luhmann A, Jeffries R, Ehsan O, Hassn A. Safety and application of laparoscopic gastrectomy for benign gastric disease and gastric cancer. Ann R Coll Surg Engl 2011; 93(1): 17 - 21. 